\title{
'Standing' Up for State Rights in Sports Betting
}

\author{
Ryan M. Rodenberg*
}

\section{Introduction}

In Gov. Murphy, et al. v. Nat'l Collegiate Athletic Ass'n, et al., ${ }^{1}$ the Supreme Court resolved one sports betting-related federalism issue and teed up another. In deciding the constitutionality of the Professional and Amateur Sports Protection Act ("PASPA"), ${ }^{2}$ the Supreme Court considered PASPA vis-à-vis the anti-commandeering doctrine embedded in the Tenth Amendment. The Supreme Court's majority opinion, written by Justice Samuel Alito, concluded: "The PASPA provision at issue here-prohibiting state authorization of sports gambling - violates the anti-commandeering rule." 3

Justice Alito also foreshadowed the next federalism issue that will likely arise in the sports betting context: "Congress can regulate sports gambling directly, but if it elects not to do so, each State is free to act on its own."4 Numerous states have accepted the Supreme Court's invitation since its ruling was released on May 14, 2018. As of April 30, 2020, more than 15 states have moved to enact sports betting laws, with dozens more considering legislation. ${ }^{5}$

Certain members of Congress have followed up too. In 2018, there was a hearing before the House Judiciary Committee about sports wagering. ${ }^{6}$ Later

\footnotetext{
${ }^{1}$ Murphy v. Nat'1 Collegiate Athletic Ass'n, 138 S.Ct. 1461 (2018).

228 U. S. C. $\$ 3701$, et seq.

3138 S.Ct. at 1478.

${ }^{4}$ Id. at $1484-85$.

${ }^{5}$ Ryan Rodenberg, United States of Sports Betting, An Updated Map of Where Every State Stands, ESPN, https://www.espn.com/chalk/story//id/19740480/the-united-states-sports-bettingwhere-all-50-states-stand-legalization (Feb. 5, 2020).

${ }^{6}$ David Purdum, Congressional Subcommittee to Review Sports Betting Landscape, ESPN, https://www.espn.com/chalk/story/_id/24741786/congressional-subcommittee-examine-sports-betting (Sept. 20, 2018).
}

"Ryan M. Rodenberg, PhD, JD, is an associate professor in the Department of Sport Management at Florida State University. 
the same year, now-retired Senator Orrin Hatch and Senator Chuck Schumer introduced a detailed sports betting bill at the federal level. ${ }^{7}$ In September 2019, news broke that Senator Mitt Romney and Schumer were "collaborating" on new sports wagering legislation. ${ }^{8}$

This ongoing confluence of state and federal efforts to regulate sports betting gives rise to weighty federalism concerns. The focus of this article is on standing, a key issue lurking in the federalism debate. Namely, does a state-or group of like-minded states - have standing to sue the United States if federal legislation fully or partially usurps existing state law pertaining to sports betting? Based on existing Supreme Court precedent, the answer is a qualified 'yes.' Certain states would have standing to sue the US or a political subdivision/appointee if federal legislation seeks to override, preempt, or otherwise nullify existing state sports wagering laws. Pointedly, states with current sports betting legislation would argue that such a lawsuit is necessary to continue to enforce its laws. Indeed, the Supreme Court found that states are "entitled to special solicitude in our standing analysis."

\section{Supreme Court Precedent}

Any state plaintiff invoking federal jurisdiction has the burden of establishing standing, ${ }^{10}$ with the Supreme Court also "ha[ving] an obligation to assure [itself] of litigants' standing under Article III." "11 The general multi-prong standing requirement requires that plaintiffs have "suffered 'an invasion of a legally protected interest' that is 'concrete and particularized' and 'actual and imminent, not conjectural or hypothetical.",'12 Likewise, plaintiffs must demonstrate an injury

\footnotetext{
7 John Holden, Instant Expert Legal Analysis of the Federal Sports Betting Bill—Part 1, LEGALSPORTSREPORT, https://www.legalsportsreport.com/26953/federal-sports-betting-bill-analysis/ (Dec. 20, 2018); John Holden, Instant Expert Legal Analysis of the Federal Sports Betting Bill—Part 2, LegalSportsReport, https://www.legalsportsreport.com/27070/federal-sports-betting-bill-analysis-2/ (Dec. 25, 2018); David Purdum \& Ryan Rodenberg, What You Need to Know About the New Federal Sports Betting Bill, ESPN, https://www.espn.com/chalk/story/ I id/25581529/what-need-know-sports-wagering-market-integrity-act-swmia-2018 (Dec. 20, 2018).

${ }^{8}$ Tony Batt, Former U.S. Presidential Nominee Mitt Romney Working on Sports Betting Bill, Gambling Compliance (Sept. 6, 2019); Tony Batt \& Jim Myers, U.S. Senator Mitt Romney Confirms Alliance on Federal Sports Betting Bill, Gambling Compliance (Sept. 11, 2019); John Holden, Remember the Federal Sports Betting Bill? Apparently It's Still a Thing, LegalSporTsREPORT, https://www.legalsportsreport.com/35368/federal-sports-betting-bill-official-league-data/ (Sept. 6, 2019); David Purdum, NCAA Wants Federal Sports Betting Legislation, ESPN, https:// www.espn.com/chalk/story//id/27586235/ncaa-pushing-federal-sport-betting-legislation (Sept. 10, 2019); Brett Smiley, Report: Romney to Carry Federal Sports Betting Bill Torch With New York's Schumer, SportsHandle, https://sportshandle.com/romney-schumer-sports-betting-federal-bill-report/ (Sept. 6, 2019).

${ }_{9}$ Massachusetts, et al. v. Environmental Protection Agency, et al., 127 S.Ct. 1438, 1454-55 (2007).

${ }^{10}$ Clapper v. Amnesty Int'l USA, 133 S.Ct. 1138, 1148 (2013).

${ }^{11}$ DaimlerChrysler Corp. v. Cuno, 547 U.S. 332, 340 (2006) (quoting Friends of the Earth, Inc. v. Laidlaw Environmental Services (TOC), Inc., 528 U.S. 167, 180 (2000).

12 Spokeo v. Robins, 136 S. Ct. 1540, 1548 (2016) quoting Lujan v. Defenders of Wildlife, 504 U.S. 555, 560 (1992).
} 
in fact traceable to the defendant's conduct and redressable by a favorable judicial decision. ${ }^{13}$ Beyond these general requirements for standing - all derived from Article III limiting judicial power to "actual, ongoing cases or controversies"14 is the tethered issue about when a state can sue the US. The Supreme Court has addressed the issue directly and indirectly in a number of cases.

\section{A. Massachusetts v. EPA}

The most prominent modern Supreme Court case to delve into the contours of state standing is Massachusetts, et al. v. Environmental Protection Agency, et al. ${ }^{15}$ The case saw Massachusetts and 11 other states intervene in a dispute about whether the Environmental Protection Agency ("EPA") had "abdicated its responsibility under the Clean Air Act to regulate the emissions of four greenhouse gases, including carbon dioxide." ${ }^{.16}$ The Supreme Court keyed in on Massachusetts among the intervening states and considered whether it had standing to sustain the litigation:

We stress here ... the special position and interest of Massachusetts. It is of considerable relevance that the party seeking review here is a sovereign State and not ... a private individual. Well before the creation of the modern administrative state, we recognized that States are not normal litigants for the purposes of invoking federal jurisdiction. ${ }^{17}$

In Massachusetts v. EPA, the Supreme Court traced the history of state standing in various cases. An early example was the 1907 case of Georgia v. Tennessee Copper Co., where Georgia established standing in a case involving air pollution. ${ }^{18}$ According to the Court: "This is a suit by a State for an injury to it in its capacity of quasi-sovereign. In that capacity the State has an interest independent of and behind the titles of its citizens." ${ }^{\prime 19}$ Justice John Paul Stevens, writing for the 5-4 majority in Massachusetts v. EPA, also addressed the socalled Mellon bar. ${ }^{20}$ The Supreme Court clarified that "there is a critical difference between allowing a State to protect her citizens from the operation of

\footnotetext{
13 Id. at 1547.

${ }^{14}$ U.S. Const. Art. III. See Lewis v. Cont'1 Bank Corp. 494 U.S. 472 , 477 (1990). Indeed, “[o] ne element of the case-or-controversy requirement" is that a plaintiff demonstrate the requisite standing to sue. Raines v. Byrd, 521 U.S. 811, 818 (1997).

15127 S. Ct. 1438 (2007).

${ }^{16} I d$. at 1446. Procedurally, the case bypassed the district court level due to the EPA's status as an administrative agency and went straight to the U.S. Court of Appeals for the District of Columbia Circuit before landing at the Supreme Court. The group of states were allied with a handful of local governments and private organizations.

17 Id. at 1454.

18206 U.S. 230 (1907).

19 Id. at 237.

${ }^{20}$ Massachusetts, et al. v. Environmental Protection Agency, et al., 127 S.Ct. 1438, 1455 n. 17

(2007), citing Massachusetts v. Mellon, 262 U.S. 447, 484-485 (1923).
} 
federal statutes (which is what Mellon prohibits) and allowing a State to assert its rights under federal law (which it has standing to do)." ${ }^{21}$ The Court explained by citing Justice Anthony Kennedy's concurrence in Lujan v. Defenders of Wildlife:

While it does not matter how many persons have been injured by the challenged action, the party bringing suit must show that the action injures him in a concrete and personal way. This requirement is not just an empty formality. It preserves the vitality of the adversarial process by assuring both that the parties before the court have an actual, as opposed to professed, stake in the outcome, and that the legal questions presented ... will be resolved, not in the rarified atmosphere of a debating society, but in a concrete factual context conducive to a realistic appreciation of the consequences of judicial action. ${ }^{22}$

The Supreme Court eventually concluded that Massachusetts "is entitled to special solicitude in our standing analysis." ${ }^{23}$ While not defining the exact parameters of what such 'special solicitude' entails, the Supreme Court's 2007 ruling is almost certainly more permissive than the threshold set forth in Spokeo v. Robins, a 2016 ruling emphasizing that a plaintiff must "allege an injury that is both concrete and particularized." ${ }^{4}$ With the Supreme Court deadlocking 4-4 in a similar case almost 10 years later involving a challenge by Texas and certain other states regarding certain federal immigration policies, ${ }^{25}$ Massachusetts $v$. EPA remains the prevailing precedent on how — and when — states can establish standing in cases when adverse to the US.

\section{B. Other Cases}

A quartet of other Supreme Court cases also provide guidance on whether states can establish standing. First, in a representative case where a state sued as parens patriae ${ }^{26}$ the Supreme Court has mandated a finding of a quasi-sovereign interest "apart from the interests of particular private parties, i.e., the State must be more than a nominal party." 27 The Supreme Court explained:

\footnotetext{
21127 S. Ct. at 1455 n. 17.
}

${ }^{22}$ Id. at 1453 (citing Lujan v. Defenders of Wildlife, 504 U.S. 555, 581 (1992) (Kennedy, J., concurring in part and concurring in judgment) (internal citations omitted).

$23127 \mathrm{~S}$. Ct. at 1455.

24136 S. Ct. 1540, 1545 (2016). The issue in the case was "whether [plaintiff] Robins ha[d] standing to maintain an action in federal court against [defendant] Spokeo under the Fair Credit Reporting Act of 1970." Id. at 1544.

25 United States, et al. v. Texas, et al., 136 S.Ct. 2271 (2016) ("The judgment is affirmed by an equally divided court.").

${ }^{26}$ According to a prominent scholar, "[h]istorically, parens patriae referred to the notion of the king as parent of the country. In that role, the king could stand as guardian for persons incapable of acting for themselves ... including bringing suits on behalf of those persons. Early American law adopted this definition of parens patriae.” F. Andrew Hessick, Quasi-Sovereign Standing, 94(5) Notre Dame L. Rev. 1927, 1933 (2019) (internal citations omitted).

${ }^{27}$ Alfred L. Snapp \& Son, Inc. v. Puerto Rico ex rel. Barez, 458 U.S. 592, 607 (1982). 
Although the articulation of such interests is a matter for case-by-case development - neither an exhaustive formal definition nor a definitive list of qualifying interests can be presented in the abstract-certain characteristics of such interests are so far evident. These characteristics fall into two general categories. First, a State has a quasi-sovereign interest in the health and well-being — both physical and economic - of its residents in general. Second, a State has a quasi-sovereign interest in not being discriminatorily denied its rightful status within the federal system. ${ }^{28}$

Second, the Supreme Court has pointed to cases "affecting the property rights and interests of a State" and involving the "prosperity of the towns and cities of the state" as sufficient to find federal jurisdiction. ${ }^{29}$ Third, the Supreme Court suggested that "a State has standing to defend the constitutionality of its statute." ${ }^{30}$ Fourth, the Supreme Court found standing in Maine v. Taylor and declared that "a State clearly has a legitimate interest in the continued enforceability of its own statutes." 31

\section{New Hampshire Lottery Case}

Whether a state has standing to pursue gambling-related claims against the federal government is not merely an academic exercise. As of April 30, 2020, litigation was on-going in the First Circuit that addressed whether a state agency had standing to sue the federal government. ${ }^{32}$ The case-New Hampshire Lottery Comm'n, et al. v. William Barr, et al.-involved the state lottery suing Attorney General William Barr and the Department of Justice("DOJ") over the DOJ's issuance of an Office of Legal Counsel ("OLC") memo pertaining to the scope of a federal criminal statute.

At issue in the case was whether the Wire Act of $1961^{33}$ attached to gambling activity beyond sports betting. ${ }^{34}$ In 2011, the OLC issued a memo stating that the Wire Act's coverage was limited to cross-state sports betting. ${ }^{35}$ In 2018 , the OLC reversed itself and issued another memo concluding that the Wire Act's prohibitions extend to interstate gambling activities beyond sports betting. ${ }^{36}$ The

\footnotetext{
${ }_{28} I d$.

${ }^{29}$ Missouri v. Illinois, 180 U.S. 208, 240-241 (1907).

30 Diamond v. Charles, 476 U.S. 53, 62 (1986).

31477 U.S. 131 (1986).

32 New Hampshire Lottery Comm'n, et al. v. William Barr, et al., No. 19-1835 (1st Cir.).

3318 U.S.C. $\S 1084$.

34386 F.Supp.3d 132 (D.N.H. 2019). While the on-going case is not focused on how the Wire Act of 1961 interacts with sports betting, its resolution could impact certain aspects of expanded sports wagering nationwide. See Ryan Rodenberg, Why a New Hampshire Legal Case Is Vital to U.S. Sports Betting Growth, ESPN, https://www.espn.com/chalk/story//id/26692134/why-newhampshire-legal-case-vital-us-sports-betting-growth (May 14, 2019).

3586 F.Supp.3d at 137.
${ }^{36}$ Id.
} 
New Hampshire Lottery promptly sued, seeking a declaratory judgment that the Wire Act of 1961 is limited to sports betting. ${ }^{37}$ The lottery also alleged that the most-recent OLC memo amounted to an imminent threat of prosecution. ${ }^{38}$

Beyond its argument on the merits, the DOJ countered with a standing argument: "[T]he Court should dismiss [this case] for lack of standing, as Article III does not permit the Court to issue an advisory opinion concerning the proper interpretation of the [Wire Act]." 39 According to the DOJ:

To have standing to bring a pre-enforcement challenge to a federal criminal statute, Plaintiffs must demonstrate that they have 'an intention to engage in a course of conduct arguably affected with a constitutional interest, but proscribed by a statute, and [that] there exists a credible threat of prosecution thereunder.' Plaintiffs cannot satisfy that standard. ${ }^{40}$

The New Hampshire Lottery responded to the DOJ's standing argument in two ways. First, the lottery explained why "a credible threat of prosecution exists sufficient to enable the [lottery] to maintain this action." ${ }^{\text {41 }}$ Describing the 2018 OLC memo as "binding," the lottery cited Babbitt v. United Farm Workers Nat. Union ${ }^{42}$ and Virginia v. Am. Booksellers Ass' $n^{43}$ for the proposition that compliance with the memo's interpretation could not occur absent the lottery taking corrective measures. Second, the lottery argued that its underlying conduct - the operation of a state-sponsored gambling venture with elements that cross state lines-amounted to an activity involving "a constitutional interest." "Specifically, the lottery cited Iannelli v. United States in positing that the "regulation of gambling activity within state borders has long been a power reserved to the States by the Tenth Amendment of the United States Constitution." ${ }^{45}$

\footnotetext{
37 Complaint, New Hampshire Lottery Comm'n, et al. v. William Barr, et al., No. 1:19-cv-00163PB (Feb. 15, 2019).

${ }^{38} \mathrm{Id}$.

39 Defendants' Memorandum in Support of Motion to Dismiss and Objections to Plaintiffs' Motions for Summary Judgment, No. 1:19-cv-00163-PB (March 22, 2019).

${ }^{40}$ Id. citing Susan B. Anthony List v. Driehaus, 573 U.S. 149, 159 (2014).

${ }^{41}$ NHLC's Memorandum of Law Objecting to Defendants' Motion to Dismiss the Comlaint [sic] and Replying to Defendants' Objection to NHLC's Motion for Summary Judgment, No. 1:19-cv00163-PB (March 29, 2019).

42442 U.S. 289, 302 (1979).

43484 U.S. 383, 392 (1988).

${ }^{44}$ NHLC's Memorandum of Law Objecting to Defendants' Motion to Dismiss the Comlaint [sic] and Replying to Defendants' Objection to NHLC's Motion for Summary Judgment, No. 1:19-cv00163-PB (March 29, 2019).

45 Id. citing 420 U.S. 770, 790 (1975) ("gambling activities normally are matters of state concern”). The lottery also cited Sterling Suffolk Racecourse Ltd. P'ship v. Burrillville Racing Ass'n, Inc., 989 F.2d 1266, 1269 (1st Cir. 1993) ("the cause of action questions what activities may lawfully be carried out at a state-regulated gambling facility, a matter traditionally relegated to state law") for the same proposition.
} 
District court judge Paul Barbadoro ruled in favor of New Hampshire on June 3, 2019.46 After initially noting that plaintiffs always "bear the burden of establishing standing, ${ }^{, 47}$ Judge Barbadoro concluded:

[T]his is no hypothetical case: The plaintiffs have demonstrated with specific record evidence that they had standing when they filed suit because a sufficiently imminent threat of enforcement loomed. The plaintiffs faced the choice between risking criminal prosecution, winding down their operations, or taking significant and costly compliance measures that may not even eliminate the threat. This choice "between abandoning [their] rights or risking prosecution ... is a 'a dilemma that it was the very purpose of the Declaratory Judgment Act to ameliorate."'48

Notably, Judge Barbadoro reached his conclusion without any discussion of whether states-or governmental sub-units and agencies-deserve special status in the standing analysis. Accordingly, it is plausible to infer that state standing in the gambling context could be established in one of two ways: the 'conventional' standing analysis most recently set forth in Spokeo v. Robins ${ }^{49}$ or the 'special solicitude' analytical prong first enunciated by the Supreme Court in Massachusetts v. EPA. ${ }^{50}$

\section{Application to Sports Betting Context}

The Sports Wagering Market Integrity Act of 2018 ("SWMIA") was formally introduced in the Senate on December 19, 2018, during the waning days of the 115th Congress. ${ }^{51}$ In a formal statement for the Congressional Record, soon-to-be retired Senator Hatch described SWMIA as "[a] bill to acknowledge the rights of States with respect to sports wagering and to maintain a distinct Federal interest in the integrity and character of professional and amateur sporting contents., ${ }^{52}$ Hatch's statement on the Senate floor also flagged "the degree to which the Department of Justice or other Federal agencies need to be involved in overseeing state sports wagering regimes, the appropriate level of control that the sports organizations should have over sports wagering, and the basis for requiring the

\footnotetext{
46386 F.Supp.3d 132 (D.N.H. 2019).

${ }^{47}$ Id. at 140, citing Susan B. Anthony List v. Driehaus, 573 U.S. 149, 158 (2014).

${ }^{48}$ Id. at 144, citing MedImmune, Inc. v. Genetech, Inc., 549 U.S. 118, 129 (2007) quoting Abbott Labs v. Gardner, 387 U.S. 136, 152 (1967).

49136 S. Ct. 1540,1547 (2016).

50549 U.S. 497 (2007).

51 “Sports Wagering Market Integrity Act of 2018," 115th Congress-Second Session (Dec. 19, 2018). Several months prior to being introduced, Senator Schumer released a two page memo highlighting how he would regulate sports betting. See Charles Schumer, Protecting the Games We Love After Murphy v. NCAA: A Federal Framework for Consumer Protection and Sports Integrity (August 2018) (on file with author).

52 “Statement by Sen. Orrin Hatch (for himself and for Sen. Charles Schumer)," Congressional Record, 115th Congress-Second Session, Vol. 164-No. 200, S7930 (December 19, 2018).
} 
use of so-called official league data" as "open questions." 53 As a proposed bill, SWMIA died without a hearing or vote. However, it has been widely reported that another federal bill modeled after SWMIA will be forthcoming. ${ }^{54}$

Numerous provisions in SWMIA — and any similarly drafted federal billwould almost certainly usurp, override, nullify, or preempt existing state law involving sports betting. Most notably, SWMIA mandated that "[t]o request approval to administer a State sports wagering program, a State shall submit an application to the Attorney General." ${ }^{55}$ Upon receipt of such an application, SWMIA would allow the DOJ 180 days to "approve the application unless the Attorney General determines that the proposed State sports wagering program does not meet the standards set forth in section 103." 56 Such standards included, but were not limited to, mandates involving the establishment of a sports betting regulatory entity, requisite sharing of information to a "National Sports Wagering Clearinghouse," certain restrictions on online betting, allowing sports leagues to request certain bets be banned, and requiring operators to purchase news and information from sports leagues or such leagues' designees. ${ }^{57}$

SWMIA did not include a provision purporting to exempt or otherwise grandfather states with existing sports betting regulatory schemes. In addition, any successful application by a state would last for only three years, with states required to apply for a renewal thereafter. ${ }^{58}$ In sum, if SWMIA or its copycat successor were to become law, state regulation of sports wagering would unequivocally be subject to federal oversight - through the (re-)application requirement and otherwise-increasing the chances that one or more states would sue to contest the imposition of such oversight.

From the time of PASPA to today, federal interest in sports betting regulation has been shaped by interested parties. Ten days after the Supreme Court issued its ruling in Gov. Murphy, et al. v. Nat'l Collegiate Athletic Ass'n, et al., ${ }^{59}$ the National Football League ("NFL") and the National Collegiate Athletic Association ("NCAA") sent a joint letter to Attorney General Jeff Sessions and Deputy Attorney General Rod Rosenstein. ${ }^{60}$ In the letter, the NFL and NCAA wrote:

\footnotetext{
${ }^{53}$ Id. Senator Hatch's mention of the DOJ's regulatory role in the proposed bill potentially implicated the doctrine of Auer deference, where - in cases of ambiguous federal regulations - the controlling agency's interpretation of such regulation should generally receive deference and control. Kisor v. Wilkie, 139 S. Ct. 2400, 2411 (2019) (citing Auer v. Robbins, 519 U.S. 452 (1997) and Bowles v. Seminole Rock \& Sand Co., 325 U.S. 410 (1945)).

54 See Batt \& Myers supra note 8.

55 “Sports Wagering Market Integrity Act of 2018," 115th Congress - Second Session, Sec. 102(a)

(1) (Dec. 19, 2018).

${ }^{56}$ Id. at Sec. $102(\mathrm{~b})(1)$.

${ }^{57} I d$.

${ }^{58}$ Id. at Sec. $102(\mathrm{~d})-(\mathrm{e})$.

59138 S.Ct. 1461 (2018).

${ }^{60}$ Letter from Jeffrey Pash (NFL) and Donald M. Remy (NCAA) to Jeff Sessions and Rod Rosenstein (DOJ) (May 24, 2018) (on file with author).
} 
To protect the integrity of our games in a post-PASPA environment, we urge the U.S. Department of Justice to immediately act, in concert with Congress, to create statutory and regulatory standards for legalized sports betting in the United States ... In the wake of the Supreme Court's decision, we are calling upon Congress and the Department of Justice to establish core standards for state regulators ... Without continued federal guidance and oversight, we worry that we will not be able to guard against the harms long associated with sports betting. ${ }^{61}$

Two months later, an NFL employee wrote a follow-up letter to the DOJ to "accept my thanks for meeting with us and the NCAA yesterday to discuss issues arising out of the Supreme Court's decision authorizing sports betting. ${ }^{62}$ The follow-up letter elaborated: "We believe that uniform federal standards will be of great value in this area, both for the protection of consumers and to safeguard the integrity of sporting events, and that this is an opportune time to put those standards into place." 63

While certain sports leagues have pushed for a federal approach to sports betting regulation, there remains strong counter-evidence that sports betting properly belongs within the purview of states. Indeed, consistent with Hatch's oxymoronic floor statement when introducing SWMIA, there is a long history of Congress and others recognizing the primary role states play in regulating gambling. ${ }^{64}$ In the Interstate Horseracing Act of 1978, Congress found that "the States should have the primary responsibility for determining what forms of gambling may legally take place within their borders." ${ }^{65}$ The DOJ concurred prior to PASPA's passage: "It is left to the states to decide whether to permit gambling activities based upon sporting events." ${ }^{\text {"66 }}$ Even the five sports leagues — who initiated and subsequently lost the Supreme Court sports betting case without garnering a single vote in support of their core federalism argument ${ }^{67}$ - acknowledged the

\footnotetext{
${ }^{61} I d$.

${ }^{62}$ Letter from Jeffrey Pash (NFL) to Jeff Sessions (DOJ) (July 17, 2018) (on file with author).

${ }^{63} \mathrm{Id}$.

${ }^{64}$ In a gambling context unrelated to sports, the DOJ has suggested that "[n]either the Taxing Clause ... nor the Necessary and Proper Clause ... of the Constitution authorizes Congress to establish a national lottery. Charles J. Cooper, Memorandum Opinion for the Assistant Attorney General, Criminal Division, Department of Justice (April 4, 1986) (on file with author). At the same time, however, the DOJ similarly concluded: "The Department of Justice believes that federal law prohibits gambling over the Internet." Letter from Michael Chertoff, Assistant Attorney General, to Dennis K. Neilander, Chairman, Nevada Gaming Control Board (August 23, 2002) (on file with author).

6515 U.S.C. $\$ 3001(a)(1)$.

${ }^{66}$ Letter from W. Lee Rawls, Assistant Attorney General, Department of Justice, to the Honorable Joseph R. Biden, Jr., Chairman, Committee on the Judiciary (Sept. 24, 1991) (on file with author).

${ }^{67}$ Notably, the DOJ's Solicitor General filed an amicus brief in support of the five sports leagues who initiated the lawsuit against New Jersey. See Brief for the United States as Amicus Curiae Supporting Respondents, Christie, et al. v. Nat'l Collegiate Athletic Ass'n, et al., Nos. 16-476, -477 (Oct. 2017). Not a single Supreme Court Justice concurred with the Solicitor General's federalism-specific argument vis-à-vis PASPA.
} 
role of states in the same context: "Whether you think gambling liberalization is a bad idea or a good one, the policy judgments of State legislatures and Congress must be respected." 68

Any state could claim that SWMIA or a similarly structured federal bill with an 'application and approval' overriding mechanism would be a direct affront to each state's existing legal framework for sports betting. New Jersey and numerous other states who supported the Garden State's Supreme Court arguments as amicus curiae have already demonstrated their willingness to litigate the issue and explicitly signaled their refusal to kowtow to federal directives when it comes to sports betting. ${ }^{69}$ To establish standing to sue, such a state-or collection of like-minded states - would, at a minimum, need to fall within the parameters of the Supreme Court's Massachusetts v. EPA decision or, in the alternative, meet the threshold requirements for standing in Spokeo v. Robins.

With the Supreme Court Massachusetts v. EPA finding that states are "entitled to special solicitude in our standing analysis," 70 it is almost certain that a state with a legal sports betting apparatus would be able to establish standing in any lawsuit against the US upon the passage of a federal regulatory law such as SWMIA. This conclusion remains firm even under a relatively narrow view of the Massachusetts v. EPA standard as articulated by prominent researcher Tara Leigh Grove: "I argue that States are entitled to 'special solicitude' in the standing analysis in only one context: when they seek to enforce or defend state law." "G1 Grove elaborated in her seminal scholarly article:

When a federal statute or administrative action purports to preempt state law, that decision has an impact much like a judicial decision striking down the state law on constitutional grounds; the State is hindered in the enforceability of its law against future private parties. The state therefore should have standing to bring suit against the federal government to protect its long-term interest in the continued enforceability of its laws- just as in Maine v. Taylor. ${ }^{72}$

\footnotetext{
${ }^{68}$ Letter from Rick Buchanan, Elsa Kircher Cole, William Daly, Tom Ostertag \& Jeffrey Pash to Members of Congress (July 30, 2007) (on file with author).

${ }^{69}$ At the cert stage, five states filed an amicus brief in support of New Jersey's cert petition. See Brief of Amici Curiae States West Virginia, Arizona, Louisiana, Mississippi, and Wisconsin in Support of Petitioners, Christie, et al. v. Nat'l Collegiate Athletic Ass'n, et al., Nos. 16-476 (November 14, 2016). At the merits stage, West Virginia led an even larger group of states and governors in filing an amicus brief in support of New Jersey's position. See Brief of Amici Curiae States West Virginia, 17 Other States, and the Governors of Kentucky, Maryland, and North Dakota in Support of Petitioners, Christie, et al. v. Nat'l Collegiate Athletic Ass'n, et al., Nos. 16-476 (September 5, 2017).

70127 S.Ct. at 1455.

71 Tara Leigh Grove, When Can a State Sue the United States?, 101 Cornell L. Rev. 851, 854-55 (2016).

72101 Cornell L. Rev. at 878.
} 


\section{Conclusion}

This article supports anti-federalists getting their foot inside the courtroom door if the federal government enacts a one-size-fits-all sports betting regulatory approach that is imposed on the states and departs from generally accepted norms of cooperative federalism. While the exact contours of state standing under Massachusetts v. EPA's 'special solicitude' standard remain hotly debated, ${ }^{73}$ even a narrow approach would support a finding of standing in the context of state sports betting laws that could be fully or partially usurped by an subsequent federal statute. Indeed, this is consistent with Grove: "[W]hen the federal government attempts to 'nullify' state law and impose a national rule, the State should have standing to protect the continued enforceability of its lawand thereby preserve the preferences and tastes of its own citizens." 74

With standing, states could potentially further a number of claims, including, but not necessarily limited to, those arising under the Intellectual Property Clause, Tenth Amendment, Takings Clause, First Amendment, and Due Process Clause. Indeed, the claims of a well-established sports gambling state like $\mathrm{Ne}-$ vada could differ from the claims of state that had only recently adopted a legal sports betting framework. Likewise, if any federal bill imposed legalized sports betting on all states, with no opportunity to opt out, a state like Utah-with its anti-gambling stance written into its state constitution - would likely bring suit against the US on additional grounds. ${ }^{75}$

\footnotetext{
${ }^{73}$ For example, the Notre Dame Law Review recently published a special issue devoted to the topic. See Tara Leigh Grove, Foreward: Some Puzzles of State Standing, 94(5) Notre Dame L. Rev. 1883 (2019).

74101 Cornell L. Rev. at 881.

${ }^{75}$ Although beyond the scope of this paper, private parties - such as sportsbook operators in possession of a license - could potentially sue the United States too. In certain limited instances, the Supreme Court has even suggested that a private party could serve as an agent for a state in litigation. Hollingsworth, et al., v. Perry, et al., 133 S. Ct. 2652 (2013).
} 